\title{
Sowiecka propaganda gazetowa na okupowanej przez Niemców Białorusi 1941-1944
}

Zarys treści: Propaganda stanowiła część wojny totalnej reżimów hitlerowskiego i sowieckiego, prowadzonej w latach 1941-1945. Na obszarze okupowanej przez Niemców Białorusi każda ze stron wykorzystywała wszystkie środki propagandowe do mobilizacji lub zastraszania społeczeństwa. Prasa komunistyczna, rozpowszechniana w warunkach konspiracyjnych, zarówno drukowana w Rosji, jak w podziemnych drukarniach, początkowo mobilizowała do walki z okupantami, a od 1943 r. przekonywała społeczeństwo o nieuchronności powrotu systemu komunistycznego i konieczności rozliczenia z wykonania obowiązków wobec sowieckiej ojczyzny.

Outline of content: Propaganda was part of the total war between the Nazi and Soviet regimes in 1941-45. In the territory of Belorussia occupied by the Germans, both states used all propaganda tools possible to mobilize or intimidate people. Initially, the communist press, distributed under conspirational circumstances, both that printed in Russia, and in underground printing houses, motivated to the struggle against the occupiers, and from 1943 on, was convincing people of the necessity to restore the communist system and account people for the fulfilment of their obligations towards the Soviet country.

Słowa kluczowe: Białoruś, propaganda sowiecka, okupacja niemiecka, prasa

Keywords: Belorussia, Soviet propaganda, German occupation, Soviet press

Przywódcy Związku Radzieckiego i III Rzeszy traktowali propagandę jako równie ważny czynnik prowadzenia wojny, co działania o charakterze militarnym. Każda ze stron na okupowanych przez Niemców obszarach zorganizowała specjalne służby do prowadzenia wojny propagandowej, przeznaczając na ten cel ogromne środki.

Głównym zadaniem sowieckiej propagandy na początku wojny była mobilizacja społeczeństwa do walki z najeźdźcą i gotowości do ponoszenia najwyższych ofiar. Niemców przedstawiano jako absolutne zło, którego tryumf grozi zagładą ludności 
na opanowanych przez nich obszarach państwa sowieckiego. Przekonywano, że jedyną szansę na przetrwanie dawało unicestwianie zła. Propaganda pokazywała bezalternatywność położenia człowieka sowieckiego, którego zadanie i przeznaczenie $\mathrm{w}$ istniejącej sytuacji stanowiła walka $\mathrm{z}$ okupantem.

Środkami propagandy były prasa, ulotki i audycje radiowe. Część druku i cały kolportaż organizowano w warunkach konspiracji. Do słabych stron publicystyki sowieckiej należały odwoływanie się do skompromitowanej ideologii komunistycznej, posługiwanie się hasłami o wolnościach obywatelskich z nadania Stalina i szczęśliwym życiu w Związku Sowieckim oraz zbawiennych skutkach kolektywizacji.

Błędy, głównie kierownictwa politycznego ZSRR, sprawiły, że w końcu czerwca 1941 r. Niemcy byli już w Mińsku, a w połowie lipca w Smoleńsku. Do uciekających $\mathrm{w}$ popłochu lub ukrywających się przedstawicieli aparatu partyjnego na Białorusi kierowano rozporządzenia i dyrektywy naczelnych władz sowieckich, podpisywane przez I sekretarza Komitetu Centralnego Komunistycznej Partii (bolszewików) Białorusi [KC KP(b)B] i członka Rady Wojennej Frontu Zachodniego Pantelejmona Ponomarienkę. Dyrektywy i rozporządzenia rozpowszechniano kanałami partyjnymi. Ich treść świadczy o braku wiedzy sowieckiego kierownictwa o nastrojach panujących wśród społeczeństwa oraz rozeznania w sytuacji zaistniałej po 22 czerwca 1941 r. Ponomarienko w rozporządzeniu z 23 czerwca 1941 r., adresowanym do obwodowych i rejonowych sekretarzy partii, polecił zorganizować grupy do niszczenia niemieckich oddziałów desantowych, uzbroić je w broń będącą w posiadaniu kołchoźników - kosy, topory, strzelby myśliwskie. Po wykryciu spadochroniarzy nieprzyjacielskich - pisal - „poinformować natychmiast oddział wojska i w żadnym wypadku nie czekać na jego przybycie, przystąpić do likwidacji wykorzystując wszystkie rodzaje broni - widły, piki, topory, szable. Wziętych do niewoli dostarczyć do jednostek wojskowych celem przesłuchania"1.

Ponomarienko znienawidzonym przez chłopów sekretarzom partii rozkazywał prowadzić ich na bój, uzbrojonych jedynie w widky i topory, przeciwko doborowym jednostkom Wehrmachtu. Mieli oni spełnić rolę, która była przypisana wyspecjalizowanym strukturom Armii Czerwonej i formacjom NKWD. Każda próba wykonania poleceń KC podpisanych przez szefa białoruskich struktur partii komunistycznej prowadzić mogła jedynie do masakry nieuzbrojonych cywilów. W trudnej sytuacji znaleźli się podwładni Ponomarienki, ponieważ otrzymali zadanie niemożliwe do wykonania, z którego w przyszłości musieli się rozliczać.

Dyrektywa KC KP(b)B, podpisana przez sekretarza Ponomarienkę, „O przejściu do podziemnej pracy organizacyjnej w rejonach zajętych przez wroga”, podobnie jak poprzednia, była adresowana do sekretarzy komitetów obwodowych, rejonowych i miejskich. Stanowiła ona polecenie przejścia do pracy konspiracyjnej, do której należało „kierowanie działalnością oddziałów i grup dywersyjnych w rejonach zajętych przez okupanta, prowadzenie wojny z oddziałami wrogiej armii, rozpalanie

\footnotetext{
${ }^{1}$ Narodowe Archiwum Republiki Białoruś (dalej: NARB), f. 4ח, op. 33a, sp. 8, k. 1.
} 
partyzanckiej wojny wszędzie i zawsze, wysadzanie mostów, dróg, składów pociągów i sieci łączności, celem stworzenia warunków nie do wytrzymania dla wroga i jego sojuszników, prześladowanie i likwidacja wrogów na każdym kroku" ${ }^{2}$. Było to polecenie zorganizowania systemu zwalczania nie tylko sił okupacyjnych, lecz także wszystkich tych, którzy w jakikolwiek sposób mieliby związek z niemieckim systemem władzy - sołtysów, urzędników, burmistrzów, policjantów, działaczy kultury, nauczycieli, kierowników zakładów pracy.

W ostatnich dniach czerwca 1941 r. do sekretarzy komitetów obwodowych $\mathrm{KP}(\mathrm{b}) \mathrm{B}$ - mohylewskiego, witebskiego, mińskiego i homelskiego - wystosowano dwie dyrektywy Państwowego Komitetu Obrony, własnoręcznie podpisane przez Stalina, oznaczone literą „H” jako rozporządzenia najwyższej wagi. W pierwszej przywódca sowiecki nakazywał bezwzględną walkę z Niemcami „do ostatniej kropli krwi” i przypominał, że obowiązkiem każdego komunisty była organizacja walki z wrogiem, a przede wszystkim niszczenie jego czołgów, szpiegów i dywersantów ${ }^{3}$. Czołgi w pierwszych dniach wojny zapewniły Niemcom przewagę nad Armią Czerwoną, dlatego kierownictwo sowieckie odwołując się do najwyższych wartości komunistycznych i patriotycznych, nawoływało członków partii, żołnierzy i zwykłych obywateli do ofiarności w zwalczaniu pancernych formacji nieprzyjaciela.

Dyrektywa nr 2 KC KP(b)B, podpisana przez Ponomarienkę, skierowana do „partyjnych, sowieckich i komsomolskich organizacji”, pt. „O poszerzaniu wojny partyzanckiej na tyłach wroga”, stanowiła poszerzoną analizę zaistniałej sytuacji politycznej i wyznaczała cele przyszłemu ruchowi oporu. Była zgodna z duchem dokumentów podpisanych przez Stalina.

Faszystowskie Niemcy - pisano we wstępie - napadły na Związek Radziecki, aby zniszczyć radziecki ustrój, zająć radzieckie ziemie, zniewolić narody Związku Radzieckiego, ograbić nasz kraj, zabrać chleb, naftę, ustanowić władzę obszarników i kapitalistów. Wróg zdradziecko napadł i zajął część naszej ojczystej Radzieckiej Białorusi. Kierownictwo Związku Radzieckiego i towarzysz Stalin ogłosili wojnę ojczyźnianą ${ }^{4}$.

Zadaniem komunistów i komsomolców - przypominał Ponomarienko - była „mobilizacja społeczeństwa do bezwzględnej rozprawy z wrogiem”.

Tym samym celom służyła dyrektywa nr 3 z końca lipca 1941 r., adresowana do obwodowych i rejonowych komitetów $\mathrm{KP}(\mathrm{b}) \mathrm{B}$, obwodowych i rejonowych komitetów wykonawczych oraz obwodowych i rejonowych komitetów komsomołu, pt. „O tworzeniu oddziałów niszczycieli czołgów”. W prawdzie wcześniej już polecono chłopom za pośrednictwem aparatu partyjnego zatrzymanie niemieckich

\footnotetext{
2 Ibidem, k. 6.

3 Ibidem, sp. 1, k. 1-7.

${ }^{4}$ Ibidem, sp. 2, k. 17-18.

${ }^{5}$ Ibidem, k. 18.

${ }^{6}$ Ibidem, sp. 2, k. 19.
} 
dywizji pancernych, lecz tym razem Ponomarienko nie tylko wskazał zadania, lecz także opisał metody niszczenia czołgów.

Czołg przeciwnika można zniszczyć łatwo - przekonywał - jeżeli działa się śmiało i zdecydowanie. Najłatwiej czołg spalić. Do tego potrzebna jest tylko butelka z benzyną. [...] Trzeba butelkami z benzyną witać czołgi, tam gdzie one się pojawią - we wsiach, zasadzkach, w lesie. Każdy niszczyciel powinien wiedzieć, że ojczyzna, partia i towarzysz Stalin ocenią za zasługi w likwidacji czołgów wroga ${ }^{7}$.

Propaganda radziecka na Białorusi, koordynowana przez KC KP(b)B, w pierwszym okresie wojny dość wiernie odzwierciedlała treści zawarte $\mathrm{w}$ dyrektywach Stalina i Ponomarienki. Społeczeństwu należało także w jakiś sposób wytłumaczyć nagłe pojawienie się nowego wroga "państwa ludu pracującego". Do 22 czerwca 1941 r. był nim angielski imperializm. Dlatego w pierwszych publikacjach po wybuchu wojny pisano i mówiono o „zdradzieckiej napaści” Niemców, z którymi dwa lata wcześniej uzgadniano nowy porządek w Europie Wschodniej. W zaistniałej sytuacji propaganda musiała dać zdecydowaną i jednoznacznie brzmiącą odpowiedź na pytania: kim są Niemcy, czym dla mieszkańców ZSRR jest tocząca się wojna i jaką postawę powinien wykazać obywatel radziecki?

Odpowiedź na pierwsze pytanie była dość prosta. Propaganda radziecka, aby być wiarygodna w tym zakresie, nie musiała nawet niczego preparować. Wystarczało opisać rzeczywistość. Określenia Niemców jako „mordercy”, „krwiożercze bestie”, "gady”, "potwory” nie były przesadzone wobec skali zbrodni popełnianych na ludności cywilnej i jeńcach Armii Czerwonej. Cel agresora - przekonywano - stanowią zabijanie, zniewalanie i grabież narodów radzieckich. Na szeroko propagowane przez Niemców w różnych przejawach hasło „Hitler wyzwoliciel”, w ulotkach podpisywanych przez KC KP(b)B odpowiadano: „Hitler wyzwala Białorusinów od chleba, ziemi i życia"8.

Czym zatem była wojna dla mieszkańców okupowanej Białorusi? Propaganda dawała jednoznaczną odpowiedź - była to wojna o biologiczne przetrwanie wspólnoty narodowej i jej poszczególnych członków. Ponieważ ojczyzna została zaatakowana przez „krwiożercze bestie”, jedyną szansę na przeżycie dawało ich unicestwianie.

Od pierwszych dni wojny przekonywano, że przewagi moralne narodu i wojska radzieckiego nad hordami zachodnich barbarzyńców przyniosą ostateczne zwycięstwo. Mieszkańcy okupowanych ziem, aby skrócić czas cierpień, poniżania i oczekiwania na wolność, mogli, a przede wszystkim mieli obowiązek pomóc Armii Czerwonej w pokonaniu wroga. Najprostszy sposób na spełnienie obowiązku to

7 Ibidem.

${ }^{8}$ Г. Болсун, Паротивостояние немеикой и советской пропаганды на окупированой теритрии Беларуси (1941-1944), в: Беларусь 1941-1945. Подвиг. Трагедия. Память, кн. 1, Минск 2010, c. 438 . 
walka zbrojna $\mathrm{w}$ formacjach partyzanckich lub okazywanie pomocy tym, którzy taką wojnę prowadzili. Propaganda pokazywała jako wzór do naśladowania wiele czynów popełnionych przez zwykłych obywateli radzieckich, które kończyły się „bohaterską śmiercią". Bohaterowie, którzy zginęli za ojczyznę - zapewniano okryli się chwałą i pozostaną w pamięci żyjących. Nienawiść do wroga i wdzięczność wobec bohaterów to dwa uczucia usilnie kreowane przez propagandę.

Propaganda chętnie odwoływała się do mitu odwiecznego starcia żywiołów słowiańskiego i germańskiego. Bitwa grunwaldzka z 1410 r. była przywoływana jako przykład zwycięstwa zjednoczonego świata słowiańskiego nad niemieckim państwem zakonnym wspieranym przez germańskich feudałów z całej Europy ${ }^{9}$.

W reakcji na niemiecką propagandę, mówiącą o wspólnocie interesów narodu niemieckiego i białoruskiego, z wielką intensywnością i żarliwym stylem opowiadano o stuleciach przyjaźni, jedności i wspólnej walce Białorusinów i Rosjan przeciwko wszystkim okupantom przychodzącym z Zachodu. Podkreślano, że cel Niemców stanowi skłócenie narodów słowiańskich, aby łatwiej można było uczynić $\mathrm{z}$ nich niewolników ${ }^{10}$.

$\mathrm{W}$ odpowiedzi na niemiecką propagandę prowadzoną w języku białoruskim, akcentującą szczególnie mocno wartości narodowe, radzieccy propagandyści podjęli próbę przelicytowania na tym polu Niemców. Zdecydowaną większość broszur, ulotek, gazet i wszelkich materiałów agitacyjno-propagandowych od końca $1941 \mathrm{r}$. drukowano w języku białoruskim. W 1941 r., gdy Armia Czerwona ponosiła klęski i cofała się na wschód, kierownictwo radzieckie szukało wszelkich możliwości mobilizacji społeczeństwa, aby odwrócić perspektywę zbliżającej się katastrofy.

Dyrektywy Stalina i Ponomarienki, obligujące komunistów do tworzenia masowego ruchu oporu, okazały się mało skuteczne wobec powszechnej apatii ze strony społeczeństwa i braku woli obrony sowieckiej ojczyzny ${ }^{11}$. Niektóre decyzje kierownictwa politycznego ZSRR dotyczące obszarów, z których wycofywała się Armia Czerwona, niosły wręcz zgubne konsekwencje dla pozostającej tam ludności cywilnej. Odwołując się do sprawdzonej w minionych stuleciach taktyki spalonej ziemi, nakazano jednostkom specjalnym palenie zasiewów na polach i zapasów ziarna $\mathrm{w}$ magazynach, aby w ten sposób osłabić potencjał aprowizacyjny wrogiej armii ${ }^{12}$. Dywersanci przerzucani na tyły Wehrmachtu rozrzucali ulotki wzywające chłopów do niszczenia zasiewów. Zaskoczeniem dla dowódców grup dywersyjnych była postawa chłopów, którzy znalezione ulotki odnosili do najbliższego posterunku żandarmerii niemieckiej, oczekując zapewne od nowej władzy ochrony plonów ${ }^{13}$.

9 Били, бъем и бить будем, „За Савецкую Беларусь” (16 IX 1941).

10 Ulotka KC KP(b)B, NARB, f. 4, op. 33a, sp. 357, k. 100.

${ }^{11}$ K. Slepyan, Partyzanci Stalina. Radziecki ruch oporu w czasie II wojny światowej, Poznań 2008, s. 53-55.

12 Rozkaz Operacyjnego Zarządu Frontu Zachodniego dla grup dywersyjnych wysyłanych za linie frontu, NARB, f. 4683, op. 3, sp. 945, k. 57.

13 Raport dowódcy grupy nr 67, z 29 VIII 1941 r., ibidem, sp. 938, k. 86. 
Rok później podziemie radzieckie nie wzywało już do niszczenia plonów i pozbawiania chłopów siebie samych żywności. Apelowano o nieoddawanie kontyngentów, chowanie zebranego z pól zboża, aby jak najmniej dostało się do dyspozycji Niemców. Po wsiach białoruskich rozrzucano ulotki KC KP(b)B, których nagłówki zawierały najważniejsze przesłanie do adresatów: „Niemieckie podatki sznur na szyi białoruskiego chłopa”, „Nie mienie, ale dwa metry ziemi na mogiłę każdemu okupantowi"14.

Intensywna propaganda przeciwko wykonywaniu przez chłopów dostaw kontyngentów produktów żywnościowych i stawiennictwu młodzieży w ośrodkach przygotowujących transporty pracowników do pracy w Rzeszy przyniosła pewne efekty. Białoruś w dziedzinie zaopatrzenia Wehrmachtu okazała się najsłabszym ogniwem Ostlandu, skąd pozyskiwano mniej niż połowę zaplanowanych dostaw produktów rolnych ${ }^{15}$. W komisariatach nadbałtyckich - Litwy, Łotwy i Estonii skuteczność ściągania kontyngentów przekraczała 80\%, zaś w Komisariacie Rzeszy Ukraina osiągano wyniki zbliżone do zaplanowanych. Jednymi z przyczyn paraliżu planów niemieckich na Białorusi były najintensywniejszy na tym obszarze ruch partyzancki i propaganda nawołująca do ignorowania rozporządzeń okupantów. Dlatego niedobory zaplanowanych kontyngentów Niemcy uzupełniali drogą nadzwyczajnych akcji rekwizycyjnych lub operacji karnych ${ }^{16}$.

Z raportów dowódców SS wynika, że operacje karne częściej były motywowane względami ekonomicznymi niż bezpieczeństwa. Niekiedy uprzedzano mieszkańców, że wieś zostanie spalona $\mathrm{z}$ powodu niedostarczenia nałożonych kontyngentów ${ }^{17}$. Ekspedycja karna miała wymusić respekt i posłuszeństwo wobec władzy niemieckiej ze strony mieszkańców sąsiednich wsi. Wysyłanie esesmanów po kontyngenty najczęściej kończyło się zagładą miejscowości. Każdą operację przeprowadzano według instrukcji obowiązującej w strukturach służb bezpieczeństwa ${ }^{18}$. Po egzekucji mieszkańców pacyfikowanej miejscowości Niemcy sprowadzali przygotowane zawczasu podwody, na które chłopi z sąsiednich wsi pod nadzorem policjantów ładowali mienie należące do zamordowanych ${ }^{19}$. Zabójstw połączonych z rabunkiem mienia ofiar dokonywano rutynowo, realizując plany gospodarcze wskazane przez kierownictwo państwa niemieckiego.

Sukces propagandy podziemia radzieckiego, wzywający do unikania dostaw kontyngentów żywnościowych oraz stawiennictwa do pracy w Rzeszy, był okupiony

${ }^{14}$ Ibidem, f. 4, op. 33a, sp. 357, k. 87, 98.

15 А. Факторович, Крах аграрной политики немецко-фашистских окупантов в Белоруссии, Минск 1979, с. 86-88.

16 Преступления немеико-фашистских окупантов в Белоруссии, ред. П.П. Липпило, В.Ф. Романовский, Минск 1965, с. 422-423.

17 Ibidem, dok. nr 18, Rozporządzenie naczelnika rejonu bogomolskiego z 17 X 1942 r., s. 41.

18 Ibidem, dok. nr 21, Rozkaz operacyjny pacyfikacji wsi Borki, Zabołocie, Borysówka z 22 IX 1942 r. podpisany przez majora policji Hollinga, s. 44-45.

19 Ibidem, dok. nr 22, Dziennik dowódcy 9 kompanii SS, zapis kapitana Kaspera o pacyfikacji wsi Borysówka z 27 IX 1942 r., s. 46-47. 
rzezią ludności cywilnej, wywiezieniem młodych ludzi jako niewolników do Rzeszy i rabunkiem mienia pomordowanych.

$\mathrm{Na}$ okupowanym terytorium Białorusi kolportowano 165 tytułów radzieckich gazet, w tym 3 centralne, 3 republikańskie, 14 obwodowych i 145 rejonowych $^{20}$. Większość stanowiły wydania jednokartkowe. Gazety centralne to "Prawda”, „Izwiestija” i „Komsomolska Prawda”.

Największe oddziaływanie miała gazeta "Sowiecka Białoruś” („Советская Белоруссия”), organ KC KP(b)B, drukowana po zajęciu Mińska przez Niemców początkowo w Orle, następnie w Kazaniu i Moskwie. Redagowano ją z myślą o rozpowszechnianiu na terytorium okupowanej Białorusi. W $1941 \mathrm{r}$. jednokartkową gazetę wydawano $\mathrm{w}$ języku rosyjskim. Pod tytułem pisma widniały apele: „Przeczytaj i przekaż następnemu” oraz „Bijcie faszystów nocą i dniem. Niszczcie ich czołgi. Palcie mosty, przeprawy, składy. Kopcie mogiły faszystowskim gadom”21.

W pierwszym okresie wojny mobilizacja własnych obywateli polegała na uporczywym powtarzaniu prostych haseł, pokazywaniu rozmiaru zbrodni niemieckich i sukcesów Armii Czerwonej, nawet wtedy, gdy ponosiła ona klęskę za klęską. Szczególnie eksponowano potrzebę niszczenia tych środków prowadzenia wojny przez Niemców, które przesądzały o ich sukcesach na froncie. Pisano więc o liczbach strąconych samolotów niemieckich przez lotników radzieckich, spalonych czołgach przez poszczególnych czerwonoarmistów, którzy mieli do dyspozycji jedynie butelki $z$ benzyną 22 . Pokazywano bohaterów i ich czyny jako wzorce do naśladowania dla innych.

Mimo ponoszonych klęsk informacje $\mathrm{z}$ frontu były $\mathrm{w}$ tym i kolejnych numerach pisma bardzo budujące ${ }^{23}$. W wydaniu „Sowieckiej Białorusi” z 4 września $1941 \mathrm{r}$. na tytułowej stronie informowano, że 1 września lotnictwo niemieckie straciło 39 samolotów, radzieckie zaś tylko 27. „Bohaterska Armia Czerwona i WojennoMorska Flota - pisano - prowadzi uporczywą walkę z faszystowskimi bandami ludożercy Hitlera”. Dalej przekazywano informację o tym, że tysiące partyzantów białoruskich codziennie walczy z faszystami, ale jednocześnie w tej samej krótkiej publikacji apelowano o intensywniejsze działania na zapleczu armii niemieckiej.

${ }^{20}$ Gazety i inne radzieckie materiały propagandowe rozpowszechniane na Białorusi w czasie okupacji niemieckiej znajdują się w elektronicznym wydaniu (CD) Biblioteki Narodowej Republiki Białoruś, pt. Паклонімся вялікім тым гадам: 65-годзю Вялікай Перамогі прысвячаецияа оraz na stronie internetowej Biblioteki: http://old.nlb.by/vov70/.

21 „Советская Бедоруссия” (4 IX 1941), № 200 (3972).

22 Г. Болсун, Паротивостояние немецкой и советской пропаганды на окупированой теритрии Беларуси (1941-1944), Минск 1999, с. 5 (mps pracy doktorskiej, egzemplarz dostępny w Bibliotece Narodowej Republiki Białoruś).

${ }^{23}$ Gazeta pod taką nazwą ukazuje się nieprzerwanie do dziś; jest prasowym organem władzy prezydenckiej. Redakcja szczyci się, że podczas okupacji niemieckiej „Sowiecka Białoruś” stanowiła potężny oręż w walce z hitlerowcami. Szerzej zob. Г. Баркун, „Советская Белоруссия” стала настоящим оружием в борьбе с гитлеровскими захватчиками, „Советская Белоруссия” (5 V 2016), № 84 (24966). 
Kierownictwo partii w odrębnym komunikacie informowało obywateli, że do ofensywy na zachodzie przystąpili Anglicy, bombardując miasta portowe Rzeszy.

Odwrotna strona, zatytułowana „Ojczyzna wzywa” („Родина зовёт”), wypełniona była patriotycznymi utworami literackimi. Większość miejsca zajmował wiersz znanego poety Piotra Glebki, pt. Do białoruskiej młodzieży (К белорусской молодёжи). Glebka pisał jeszcze w stylu drugiej połowy lat trzydziestych, o swobodach z nadania Lenina i szczęściu, którym Stalin obdarował radziecką młodzież.

Вам с колыбели не знакомы
Позор ярма и власть кнута
Но вот под нашим мирным домам
Пависла черная пята
Ужели склоните колены
Вы, кто печали не знает
Вы, кому свободу дал Ленин
Вы, кому Сталин счасте дал? ${ }^{24}$

Ponieważ młodzież białoruska doświadczyła już szczęścia otrzymanego od Stalina, takie zaklęcia propagandowe często trafiały w próżnię lub powodowały skutki odwrotne do zamierzonych. Propaganda hitlerowska rozpisująca się o kolektywizacji i zniewoleniu narodu nawiązywała w jakimś stopniu do niedawnej rzeczywistości. Dlatego w 1942 r. propagandyści radzieccy zaczęli uwzględniać fakt istnienia konkurencji w walce o umysły ludności okupowanej Białorusi. Latem tego roku gazeta miała już tytuł i treść w języku białoruskim. Treść apeli zamieszczonych pod tytułem pisma pozostała podobna do tej sprzed roku. „Przeczytaj i przekaż innemu” oraz „Partyzanci! Więcej aktywności! Wszelkimi środkami niszczcie niemieckich krwiożerców. Mocniej uderzajcie na szlaki komunikacyjne wroga: niszczcie parowozy, składy pociągów, dewastujcie tory, wysadzajcie i palcie magazyny, składy paliw" 25 . Treść apelu do partyzantów wskazywała jednocześnie, jakie środki, będące do dyspozycji Niemców, dowództwo sowieckie uznawało za stanowiące największe zagrożenie dla Armii Czerwonej. Dalej na stronie tytułowej widniały hasła wzywające do określonych czynów:

\footnotetext{
${ }^{24} \mathrm{~W}$ dosłownym tłumaczeniu:

„Wam od kołyski nieznana

Hańba jarzma i władza knuta

Ale oto nad naszym spokojnym domem

Zawisła czarna pięta

Czyżby zegniecie kolana

Wy, którzy smutku nie znacie

Wy, którym wolność dał Lenin

Wy, którym Stalin szczęście dał”. „Советская Белоруссия” (14 VII 1942), № 69 (7399).

25 „Савецкая Беларусь” (12 VIII 1942), № 72 (7402).
} 

gada!"

- „Jeżeli chcesz, aby kraj nasz był piękny, a naród był wolnym - zabij Niemca

- „Bij Niemca bagnetem, bij Niemca granatem! Niemcy to nie ludzie, to okrutni kaci!"

- „Za przelaną krew i potworne zbrodnie, za pogorzeliska wiosek i ruiny miast, posyłajcie faszystów do grobu na wieki. Niech ziemię naszą użyźni ich czarna krew!”

- „Nie dawaj nigdy Niemcu spokoju, Niemcu potworowi! Za grabież i rozboje niech zapłaci głową!”

Poza apelem do partyzantów i hasłami wzywającymi do fizycznej likwidacji Niemców, główną część materiałów publicystycznych stanowiły opisy zbrodni okupantów popełnione na ludności cywilnej. Szczególnie wstrząsający był opis zabójstwa trzech chłopców w Kryczewie, którzy na ulicy śpiewali pieśń o zwycięstwach marszałka Woroszyłowa. Przechodzący żandarm zastrzelił wszystkich. Rodziców chłopców Niemcy zobowiązali stawiać się codziennie na posterunku policji, lecz - jak podaje gazeta - oni uciekli i codziennie rzucali granaty w kierunku hitlerowskich funkcjonariuszy. Ich postawę wskazywano jako przykład prawidłowego zachowania człowieka sowieckiego.

Pismo w odrębnej publikacji informowało, że na ziemi sowieckiej, tam gdzie nie dotarły niemieckie hordy, toczy się normalne białoruskie życie. W Moskwie zebrało się plenum Związku Sowieckich Pisarzy Białoruskich, które opracowywało kierunki pracy ideologicznej na rzecz zwycięstwa nad faszyzmem.

Wkrótce w „Sowieckiej Białorusi” zaczął ukazywać się czterostronicowy dodatek literacki. Pismo z twórczością literacką poszerzono do ośmiu stron. W sierpniu 1943 r. na stronie poświęconej literaturze ukazał się wiersz Pimena Panczenki, pt. Ballada o Mikołaju Sosnowskim. Poeta opowiada, jak czerwonoarmista Sosnowski swoim ciałem zasłonił gniazdo niemieckich karabinów maszynowych i umożliwił w ten sposób zdobycie towarzyszom wioski Kamienna Góra. Jedna ze zwrotek brzmi:

3 магілы ні слова ні гуку

І рота зноуку усстала:

Наперад, сябры, за Міколу!

Для помсты крыві гэтай мала ${ }^{26}$

Postawa Sosnowskiego stanowiła przykład poświęcenia człowieka radzieckiego dla ojczyzny, walki za wszelką cenę i wszelkimi metodami, do czego od początku wzywała partia. Cytowana zwrotka mówi, że z imieniem bohatera na ustach poderwała się do ataku jego kompania. Wszystkie opowiadania w tym

\footnotetext{
${ }^{26} \mathrm{~W}$ dosłownym tłumaczeniu: „Z mogiły ani słowa, ani odgłosu Ale kompania znów powstała - Naprzód, przyjaciele, za Mikołaja!

Dla zemsty krwi tej za mało”. „Савецкая Беларусь” (VIII 1943), dodatek literacki, nr 4.
} 
dodatku literackim pokazują wzorce bohaterskiego zachowania żołnierzy, partyzantów i zwykłych obywateli. Tytuły dzieł znanych pisarzy (Kuźma Czorny, Chrzest bojowy; Maksym Łużanin, Opowieść o komisarzu; Anatol Astejka, Opowieść o tym jak Filip Niemców wziąt do niewoli) znakomicie korespondują z ich treścią. Opowiadanie o Filipie pokazuje, jaką przewagę nad wrogiem mogły dawać roztropność i odwaga zwykłego obywatela radzieckiego.

Numer gazety, który ukazał się z datą 27 listopada 1943 r., prawie w całości został poświęcony wyzwoleniu Homla ${ }^{27}$. Na pierwszej stronie wielkimi literami widoczne zdanie: „Armia Czerwona wyzwoliła Homel”. Było to pierwsze wyzwolone wielkie miasto na terenie BSRR, dlatego temu wydarzeniu postanowiono nadać wielki rozgłos propagandowy. Treść stanowią reportaże pokazujące walki o Homel oraz rozkaz Stalina nadający jednostkom, które brały udział w zdobywaniu miasta, zaszczytnego miana „homelskich”. Były zatem „homelska dywizja”, pułki i bataliony $\mathrm{z}$ taką nazwą.

W 1944 r. każdy numer miał cztery strony. Oprócz informacji o zwycięstwach Armii Czerwonej pisano o odbudowie kołchozów na wyzwolonych obszarach Białorusi, uruchamianych szkołach i bibliotekach. Dużo uwagi poświęcano sytuacji międzynarodowej. Informacje o walkach na froncie zachodnim zamieszczano w każdym wydaniu gazety. Utwierdzały one obywateli radzieckich na okupowanych obszarach w przeświadczeniu o nieuchronnej klęsce Niemiec. Propaganda dawała do zrozumienia, że ci, którzy podjęli współpracę z reżimem okupacyjnym, mieli ostatnią szansę na zmycie swojej winy i hańby.

Kolejnym organem prasowym KC KP(b)B, adresowanym do mieszkańców okupowanej Białorusi, było pismo „Za Sowiecką Białoruś” („За Совецкую Беларусь”). Początkowo miało być adresowane do żołnierzy Armii Czerwonej narodowości białoruskiej i w takim charakterze wydawano je od lipca $1941 \mathrm{r}$. do czerwca $1942 \mathrm{r}^{28}$ W końcu 1943 r. zaczęło ukazywać się jako organ Kleckiego Rejonowego Komitetu KP(b)B. Pismo w treści nie nawiązywało do spraw lokalnych, adresowane było do wszystkich mieszkańców Białorusi i kolportowane na całym okupowanym obszarze $^{29}$. Bliżej nieznane względy konspiracyjne przemawiały prawdopodobnie za tym, aby nazwać je organem komitetu partii najniższego szczebla.

Pisma obwodowe i rejonowe pojawiły się nieco później, gdy w 1943 r. dokonał się przełom na froncie, a na obszarach okupowanych przez Niemców powstały w miarę stabilne struktury polityczne i militarne podziemia sowieckiego. Większość stanowiły pisma jednokartkowe publikujące materiały według określonego schematu, który był zalecany przez ośrodki odpowiedzialne za propagandę partii. Sposób oddziaływania na adresatów dość dobrze widać na podstawie treści

27 „Савецкая Беларусь” (27 XI 1943), № 113 (7554).

28 Т. Лысова, Как советская пропаганда подавляла нцыьскую, „Рэспубліка”, http://bsj.by/2013/07/ smi-i-vojna-kak-sovetskaya-propaganda-podavlyala-nacistskuyu/ (dostęp: 12.05.2018).

29 Poszczególne numery pisma znajdują się w zespołach dokumentów dotyczących podziemia sowieckiego ze wszystkich obwodów Białorusi, przechowywanych w NARB. 
zamieszczanych w gazecie „Za Sowiecką Białoruś”. Inne gazety wydawane jako rejonowe miały zresztą bardzo podobny charakter.

W pierwszym numerze organu Kleckiego Rejonowego Komitetu KP(b)B, który ukazał się z datą 27 października 1943 r., większość treści stanowi opis sukcesów Armii Czerwonej i wykaz wyzwolonych przez nią miast i rejonów. Obok tytułu widnieje apel do „Mieszkańców i mieszkanek wsi!” Partia tym razem nie wzywała chłopów do desperackiej walki z okupantami, lecz chowania żywności, której potrzebowały Armia Czerwona i ludność Związku Radzieckiego. Pisano zatem: „Nie dawajcie ani grama chleba, mięsa i innych produktów rolnych podłej niemczurze. Chowajcie od Niemców zwierzęta i wszelki swój majątek. Niech puchną z głodu nienawistni okupanci”. Jedyny artykuł w numerze, obok haseł i apeli, dotyczył także tego problemu. Przypominano w nim mieszkańcom Białorusi, że Niemcy rabowali majątek podczas pacyfikacji wsi, zabijali kobiety i dzieci, młodzież zaś uprowadzali jako niewolników do pracy w Rzeszy. Ostrzegano, że wobec zbliżania się Armii Czerwonej okupanci zechcą zabrać jak najwięcej bogactw, a mieszkańców zamordować głodem. Dlatego partia wzywała chłopów, aby jak najszybciej dokonali omłotów zebranego latem zboża i dobrze schowali ziarno. „Chowajcie zboże, aby nie trafiło do rąk niemieckich bandytów i drapieżników"30 - pisano w zakończeniu artykułu.

Na pierwszej stronie wszystkich gazet, gdzie wcześniej w partyjnej prasie widniało hasło „Proletariusze wszystkich krajów łączcie się”, umieszczono inne motto: „Śmierć niemieckim okupantom”.

Kolejne wydania pisma służyły już przygotowaniu społeczeństwa do powrotu radzieckiej rzeczywistości. Treść publikacji ukazujących się od 1944 r. przypominała publicystykę z końca lat trzydziestych. Nakład z datą 22 stycznia 1944 r. w całości poświęcony był wspomnieniu o zasługach i wielkości intelektualnej bolszewickiego przywódcy Włodzimierza Lenina. Obok tytułu wyróżniał się cytat z wypowiedzi Stalina: „Pamiętajcie, kochajcie i studiujcie Ilicza, naszego nauczyciela i naszego przywódcę. Walczymy i zwyciężamy wrogów wewnętrznych i zewnętrznych po iliczowsku. Budujcie nowe życie, nowy byt, nową kulturę po iliczowsku". Resztę stanowił jeden artykuł zatytułowany 20 lat bez Lenina na leninowskim szlaku ${ }^{31}$. Przypomniano, jak bohatersko Lenin walczył z carskim reżimem, a następnie $\mathrm{z}$ kapitalistami, aby w końcu przekazać władzę robotnikom i chłopom.

Tuż po rewolucji - pisano - Lenin poprowadził kraj po nowej drodze, do wolności i szczęścia wszystkich narodów. [...] Nikt inny, a tylko Lenin z towarzyszem Stalinem stworzyli i zorganizowali Związek Socjalistycznych Republik Radzieckich. Zabrakło Lenina, ale jego sprawa żyje wśród nas. 20 lat bez Lenina na leninowskim szlaku prowadzi sowiecki naród J. W. Stalin. Przysięgę złożoną nad grobem niezapomnianego Lenina na szczęście wykonuje obecnie towarzysz Stalin.

30 Не спажываць немцам нашы багащці, „За Совецкую Беларусь” (27 Х 1943).

3120 лет без Леніна на ленінскім шляху, „За Савецкую Беларусь” (22 I 1944), № 4 (6). 
Przywództwo Stalina służyło oczywiście - według gazety - „szczęściu” obywateli radzieckich.

Chociaż trwała wojna, ale wraz ze zbliżaniem się frontu z propagandy adresowanej do Białorusinów znikły treści służące mobilizacji społeczeństwa do walki z okupantami, pojawiły się natomiast budujące prestiż Stalina, Armii Czerwonej i partii komunistycznej. Przywódcy partyjni zdawali sobie sprawę, że prawie trzy lata indoktrynacji niemieckiej mogły wywołać skutki niwelujące efekty wcześniejszej polityki. Dlatego prasa partyjna intensywnie przypominała, że wkrótce zacznie obowiązywać radykalnie odmienna od hitlerowskiej hierarchia wartości.

Niektóre kolejne wydania pisma Kleckiego Rejonowego Komitetu partii wypełniały rozkazy Stalina, których treść opisywała zasługi poszczególnych generałów, za co głównodowodzący odznaczał ich różnymi medalami lub awansował na wyższe stopnie $^{32}$. Inne numery zaś składały się z cytatów wypowiedzi Stalina, najczęściej $\mathrm{z}$ odwołaniem się do autorytetu Lenina, traktowanego niemal jak biblijny prorok. „Wielki Lenin, który zbudował nasze państwo, mówił, że podstawową jakością ludzi sowieckich powinno być męstwo, odwaga, brak strachu i gotowość bić się razem z narodem przeciwko wrogom naszej Ojczyzny" ${ }^{33}$ - cytowano szefa partii i głównodowodzącego armii.

Od lutego 1944 r. kolejne numery świadczą o tym, że gazeta ukazywała się co drugi dzień, zachowując konsekwencję w sprawie publikowanych treści. Stronę tytułową zajmowały refleksje, myśli lub rozkazy Stalina. W wydaniu $\mathrm{z}$ datą 27 lutego głównodowodzący podzielił się z czytelnikami własną oceną pozycji Związku Radzieckiego na arenie międzynarodowej. Udowadniał, że ZSRR okazał się silniejszy niż kiedykolwiek była carska Rosja. Podczas I wojny światowej bowiem Rosja mając takich sojuszników, jak Japonia, Włochy, Rumunia, Francja i Finlandię jako własną prowincję, przegrała wojnę z Niemcami. ZSRR natomiast wygrywa wojnę - konstatował Stalin - $\mathrm{z}$ całą zjednoczoną przez Niemcy Europą ${ }^{34}$.

$\mathrm{KC} \mathrm{KP}(\mathrm{b}) \mathrm{B}$ podejmował próby zachowania ciągłości druku i kolportażu na terenie okupowanej Białorusi drugiego swojego organu prasowego - „Звязда” („Zwiazda”). Do końca lipca 1941 r. pismo było wydawane w Mińsku. Następnie redakcje przenoszono kolejno do Mohylowa i Homla. W odróżnieniu od „Sowieckiej Białorusi” „Zwiazda” miała być redagowana i drukowana w warunkach konspiracyjnych. W maju 1942 r. stała się organem prasowym Mińskiego Komitetu Miejskiego KP(b)B. Pierwszy numer wydrukowano w zakładzie poligraficznym należącym do Niemców. Likwidacja pisma $\mathrm{z}$ tego m.in. powodu stała się celem pierwszoplanowym dla władz okupacyjnych. Dwa tygodnie po ukazaniu się pierwszego numeru został zamordowany redaktor gazety Włodzimierz Omieljaniuk. Od czerwca do września wydano jeszcze trzy numery. Kolportowano je głównie na

32 „За Савецкую Беларусь” (6 II 1944), № 6 (18).

33 „За Савецкую Беларусь” (19 II 1944), № 7 (19).

34 „За Савецкую Беларусь” (27-29 II 1944), № 10-11 (23). 


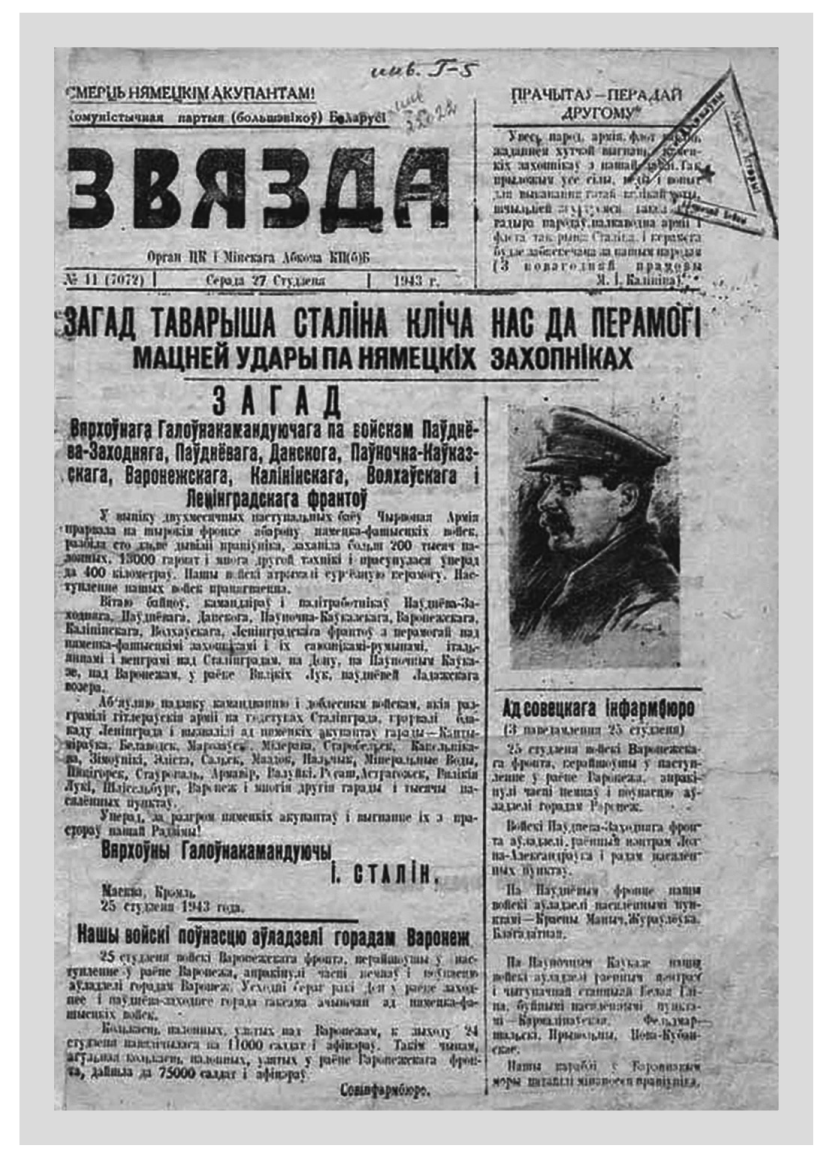

1. „Zwiazda” (27 I 1943), nr 11 (7079).

terenie Mińska. W wyniku działań niemieckich organów bezpieczeństwa zginęła większość redakcji i wydawanie gazety zawieszono do stycznia $1943 \mathrm{r}$.

„Zwiazda” jako organ Mińskiego Komitetu Miejskiego partii zamieszczała głównie publikacje mobilizujące do walki z okupantami. Apel obok tytułu wzywał partyzantów i partyzantki: „Bezlitośnie niszczcie krwawych hitlerowskich bandytów! Bracia i siostry - Białorusini! Razem z partyzantami pomagajcie Armii Czerwonej szybciej wyzwolić swoją ojczyznę. Organizujcie się w oddziały partyzanckie". Podobnie jak inne gazety, pismo latem 1942 r. zapowiadało wyzwolenie Białorusi od „niemieckich gadów”. W czasie gdy armia niemiecka zbliżała się do Wołgi i Kaukazu, pisano o fiasku planów Hitlera. Wiarę w rychłe zwycięstwo miała umacniać także obszerna informacja o przygotowaniach Anglików i Amerykanów do utworzenia drugiego frontu na zachodzie Europy. Oczekiwania władz sowieckich pod adresem sojuszników przedstawiano wówczas niemal jako fakty dokonane. 


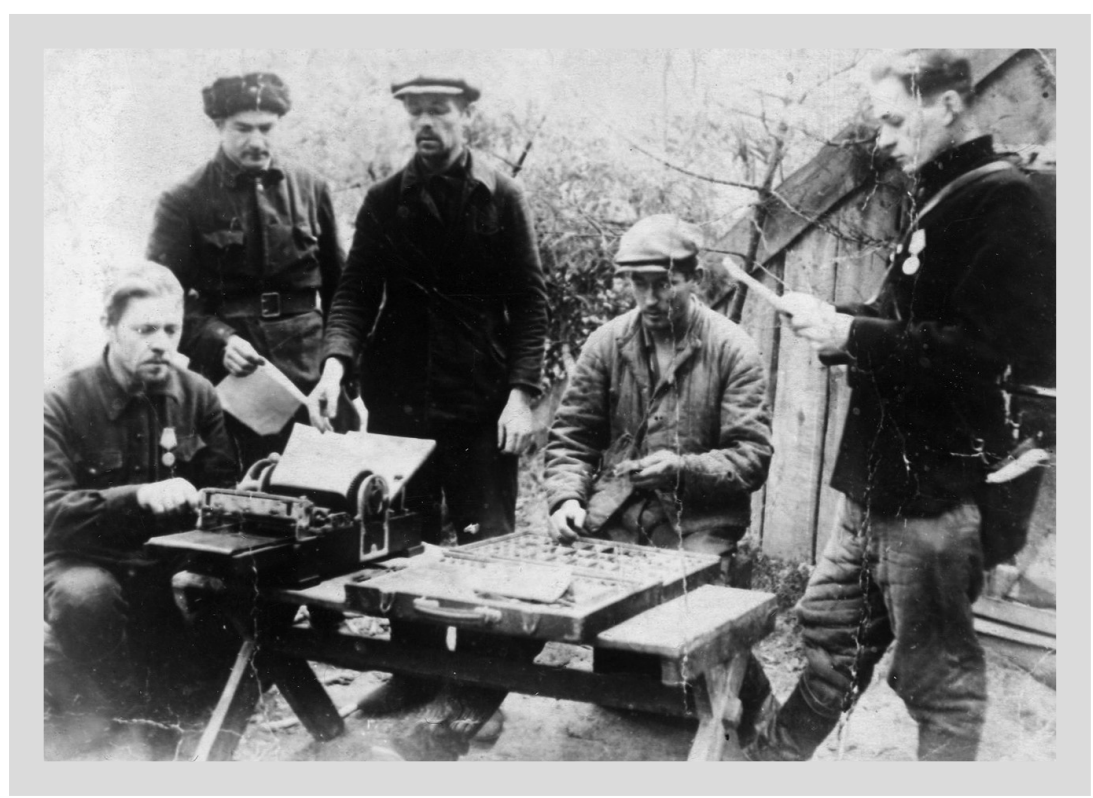

2. Partyzancka drukarnia, NARB, f. 1487, op. 1, sp. 165, k. 3.

Po wznowieniu wydawania pisma na początku 1943 r., zaczęło się ono ukazywać jako organ prasowy KC i Mińskiego Komitetu Miejskiego KP(b)B. Gazetę drukowano $\mathrm{w}$ obwodzie mińskim $\mathrm{w}$ rejonie kontrolowanym przez partyzantów. Wydawano regularnie aż do wyzwolenia Mińska na początku lipca $1944 \mathrm{r}$.

Podobnie jak „Sowiecką Białoruś” i „Za Sowiecką Białoruś”, treść „Zwiazdy” w 1943 r. zdominowały rozkazy Stalina i informacje o zwycięstwach Armii Czerwonej. Realna perspektywa powrotu władzy sowieckiej bardziej mobilizowała obywateli do okazywania patriotycznych postaw, niż wcześniejsze apele partii ${ }^{35}$.

Najmocniej przemawiającymi do wyobraźni materiałami propagandowymi były pisma satyryczne. Formą i treścią bardziej przypominały plakaty niż gazety. Wyjątkowe miejsce wśród wydawnictw satyrycznych zajmował periodyk „Zmiażdżymy faszystowskiego gada” („Раздавім фашысцкую гадзіну”). Podobnie jak "Sowiecka Białoruś" było to wydanie KC KP(b)B. Pismo ukazywało się od lipca 1941 do maja 1945 r. nakładem od kilkuset do tysiąca egzemplarzy. Pierwsze numery drukowano w Homlu, następne w Moskwie, a od 1944 r. ponownie w Homlu. Obraz, krótkie wiersze i hasła stanowiły główną treść przekazu. Pismo tworzyli najwybitniejsi białoruscy poeci, pisarze i rysownicy - wśród nich Janka Kupała, Jakub Kołas, Kuźma Czorny, Konrad Krapiwa, Paweł Browka.

W numerze z lutego 1942 r. na górze pozdrowienia białoruskim partyzantom, na dole apel w stylu i retoryce czasu wojny: „Bijcie, gromcie niemczurę, dopóki na

35 „Звязда” (27 I 1943), № 11 (7079). 


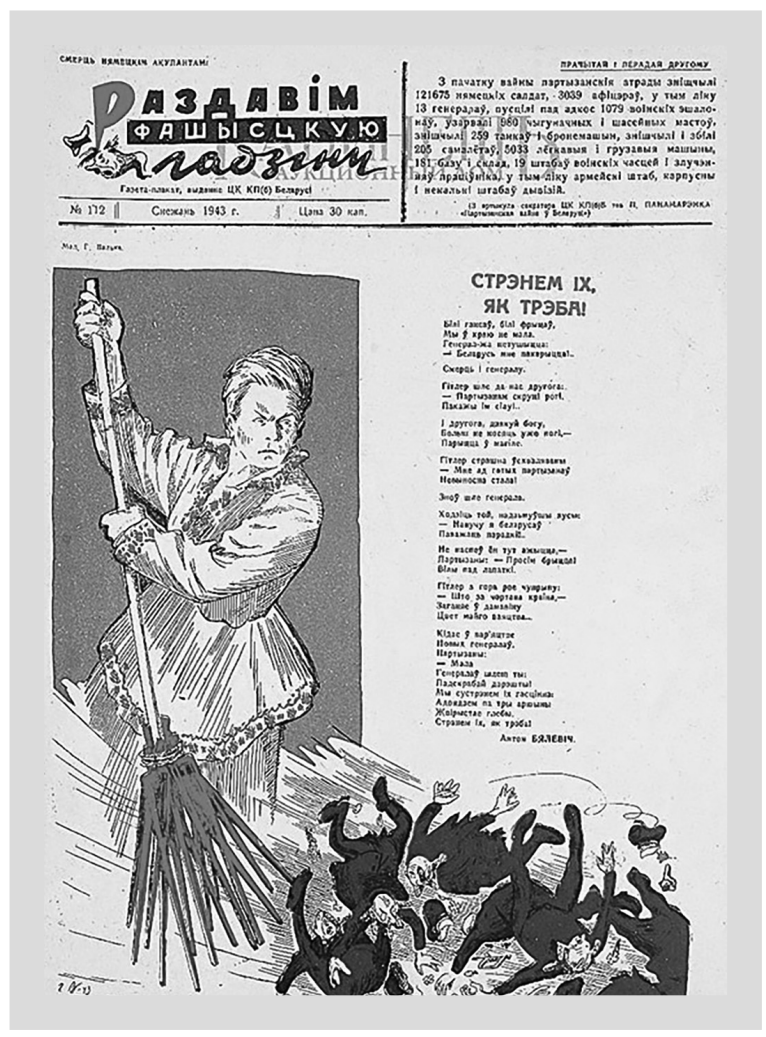

3. „Zmiażdżymy faszystowskiego gada” (XII 1943), nr 112.

naszej ziemi nie pozostanie ani jednego faszysty”. Trzy krótkie publikacje dotyczyły Hitlera. Ich tytuły są ważniejsze od treści: Biblia ludożercy, Ostatnia stawka Hitlera, Śnił się wronie lot orła ${ }^{36}$. Wszystkie ośmieszały wodza III Rzeszy i zapowiadały jego klęskę $\mathrm{w}$ wojnie $\mathrm{z}$ ZSRR. Sytuacja na froncie $\mathrm{w}$ tym czasie nie dawała najmniejszych podstaw do takich przepowiedni.

Równie optymistyczny dla mieszkańców okupowanej Białorusi był numer gazety, który ukazał się miesiąc później. Na plakacie żołnierze Armii Czerwonej, wspomagani przez samoloty i czołgi, informują: „Białoruś, my już idziemy”. Niżej krótki tekst Kołasa Gwiazda wyzwolenia zabłyśnie nad Białorusią. Poeta zapowiadał, że huk armat ze wschodu będzie początkiem końca niewoli, „ciemnej nocy cierpień”, „przyniesie radość wolności” i „jasność słonecznego dnia”. „Armia Czerwona - pisał - żelazną miotłą wymiecie grabieżcze hordy oszalałego faszyzmu" ${ }^{\prime 3}$. W rzeczywistości jeszcze przez wiele miesięcy Armia Czerwona cofała się na wschód. Na granicach Republiki Białoruś pojawiła się dwa lata później.

\footnotetext{
36 „Раздавім фашысцкую гадзіну” (II 1942), № 3.

37 „Раздавім фашысцкую гадзіну” (III 1942), № 39.
} 


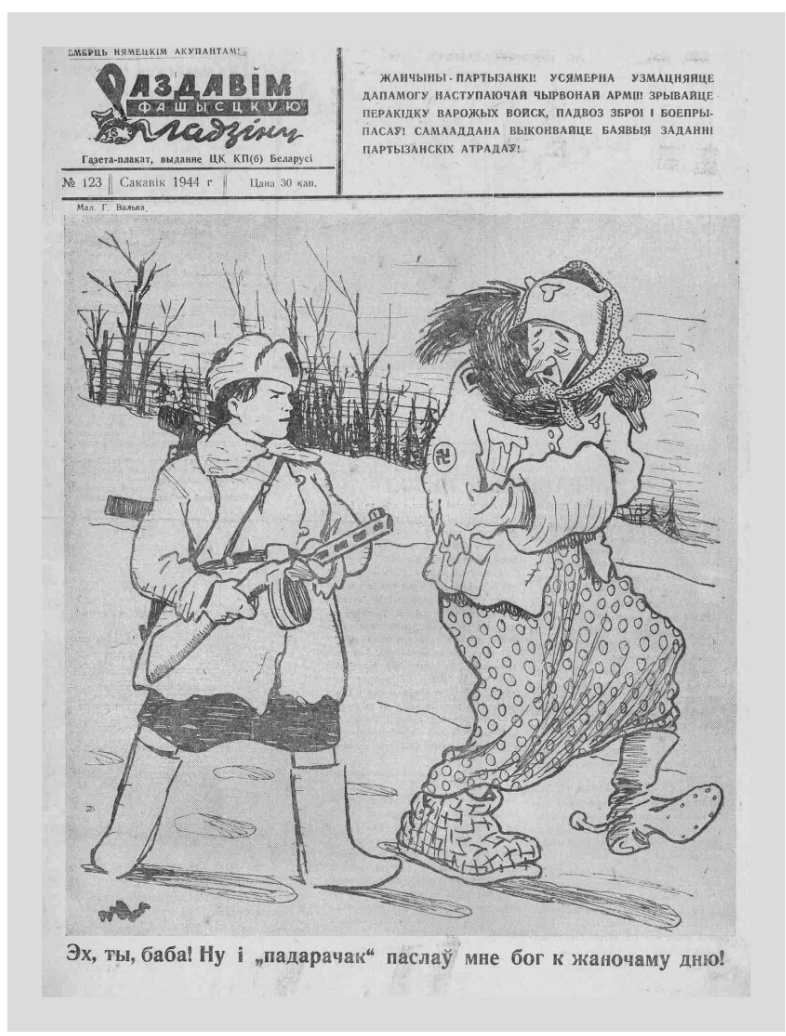

4. „Zmiażdżymy faszystowskiego gada” (III 1944), nr 123.

Publikowane rysunki i hasła dopasowywano do zmieniającej się rzeczywistości. W końcu 1943 r. wynik wojny na wschodzie był możliwy do przewidzenia. Gazeta-plakat z grudnia 1943 r. zapowiadała wymiatanie faszystowskiego śmiecia $\mathrm{z}$ Białorusi. Dopełnienie stanowiła informacja od I sekretarza KC KP(b)B Ponomarienki o ponad 120000 wyeliminowanych przez białoruskich partyzantów żołnierzy niemieckich, 3000 oficerów, w tym 13 generałach, zniszczonych 1079 składach pociągów i 259 czołgach oraz 205 zestrzelonych samolotach. Wielkie sprzątanie „żelazną miotłą” miało nastąpić wraz z nadejściem Armii Czerwonej ${ }^{38}$.

W szczególny sposób wydawcy pisma uczcili w 1944 r. Święto Kobiet. W apelu do partyzantek wzywano do podejmowania samodzielnych akcji dywersyjnych przeciwko niemieckim transportom z zaopatrzeniem dla armii niemieckiej. Plakat pokazuje młodą partyzantkę konwojującą pojmanego Niemca przebranego za kobietę. „Cóż za "prezent» przysłał mi Bóg w Dniu Kobiet!”39 - narzekała bohaterska dziewczyna.

38 „Раздавім фашысцкую гадзіну” (XII 1943), № 112.

39 „Раздавім фашысцкую гадзіну” (III 1944), № 123. 


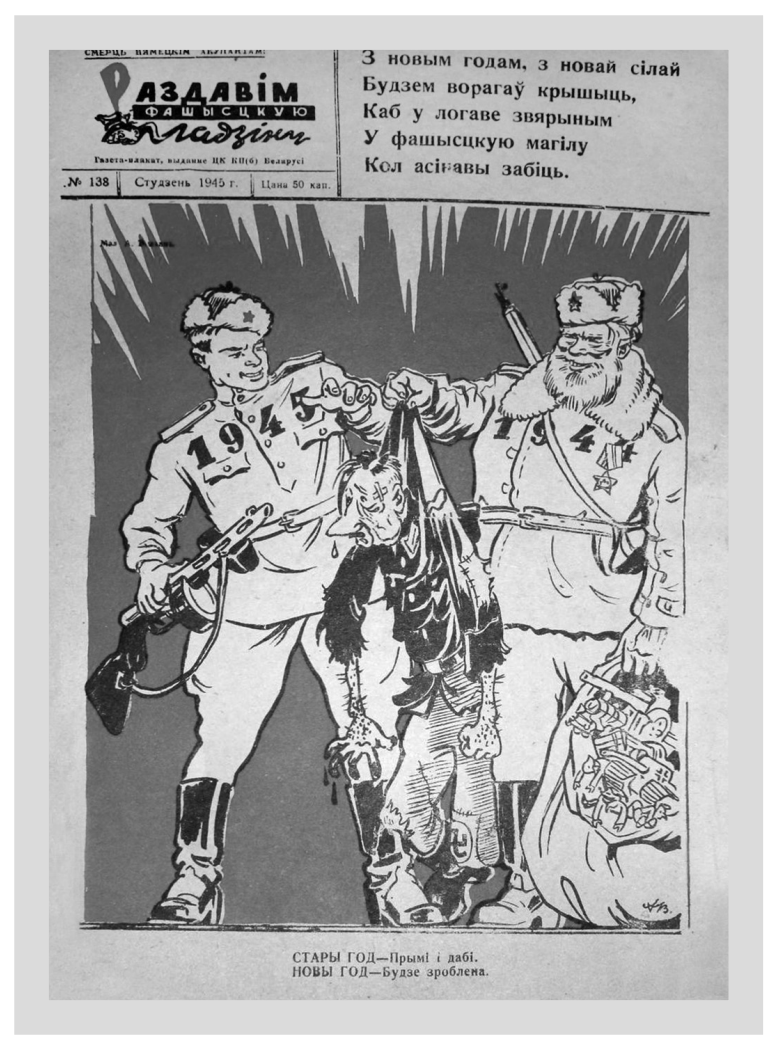

5. „Zmiażdżymy faszystowskiego gada” (I 1945), nr 138.

Na przełomie 1944 i 1945 r. Armia Czerwona wyzwoliła wszystkie okupowane obszary ZSRR i zmierzała w kierunku granic niemieckich. Na plakacie Stary Rok 1944 przekazuje obdartego osobnika $\mathrm{z}$ wizerunkiem podobnym do Hitlera z życzeniem „Weź i dobij”. Nowy Rok 1945 odpowiada: „Będzie zrobione” 4 .

Pismo satyryczne „Partyzancki Kij” („Партызанская дубінка”) stanowiło dodatek do gazety „Za Wolną Białoruś” („За Свабодную Беларусь”). Вyła ona wydawana w języku białoruskim przez Zarząd Polityczny Frontu Kalinińskiego przy udziale KC KP(b)B. Miała być przeznaczona do kolportażu na okupowanych obszarach. Redaktorem był dramatopisarz Ilia Górski, który przed wojną redagował w Mińsku pismo w języku białoruskim „Literatura i Sztuka” („Літаратура і мастацтва”). Wśród współpracowników było wielu radzieckich intelektualistów, których publikacje zamieszczano także $\mathrm{w}$ „Sowieckiej Białorusi” $\mathrm{i}$ innych pismach ukazujących się jako wydawnictwa $\mathrm{KC} \mathrm{KP}(\mathrm{b}) \mathrm{B}^{41}$. Siła ruchu partyzanckiego na

40 „Раздавім фашысцкую гадзіну” (I 1945), № 138.

41 С. Стыкалин, Советская сатирическая печать 1917-1963. Партызанская дубінка, https:// info.wikireading.ru/249308 (dostęp: 12.03.2019). 
terytorium Białorusi dla Frontu Kalinińskiego osłaniającego Moskwę miała ogromne znaczenie. Kierownictwo radzieckie oczekiwało od podziemia na Białorusi działań paraliżujących zaopatrzenie Wehrmachtu. Stąd intensywne działania propagandowe podkreślające przewagę moralną, intelektualną i logistyczną partyzantów nad okupantami, gwarantujące im ostateczne zwycięstwo i miejsce w panteonie bohaterów.

Gazeta i dodatek satyryczny były wydawane od marca 1942 do marca 1943 r. W „Partyzanckim Kiju” pokazywano przede wszystkim potęgę ruchu partyzanckiego, bezsilność, okrucieństwo i zakłamanie propagandy niemieckiej. W pierwszym numerze, z 22 marca 1942 r., prezentowano w komiksowej wersji spryt partyzanta, który w przebraniu kobiecym niósł mięso ze wsi do lasu. Dwaj Niemcy mając nikczemne zamiary, ruszyli za kobietą, którą okazał się uzbrojony partyzant. Przekonywano adresatów tej satyry, że wystarczy trochę odwagi i chłopskiej przebiegłości, aby ujrzeć hitlerowców z podniesionymi rękami ${ }^{42}$.

W lipcowym wydaniu satyrycznego dodatku gazety „Za Wolną Białoruś” (5 VII 1942 , nr 6) jeden rysunek, opisany rymowanym wierszem, opowiadał o marzeniach niemieckich po podboju Wschodu, drugi o napotkanej tu rzeczywistości. Marzył zatem Niemiec, że zostanie panem, będzie żyć w pałacu, „kąpać się w złocie”, a dla wzmocnienia aryjskiego ducha niepokornych chłopów wieszać. Tablica widoczna na drugim rysunku o rzeczywistości na okupowanych obszarach wieszczyła „psom psią śmierć”. W formie poetyckiej opisano białoruskie realia: „Gdy tak hitlerowiec marzył, nieoczekiwanie piorun uderzył. Partyzanckie granaty wybiły głupotę z katów". Poeta ukazujący dzieło rysownika w zakończeniu rolę Niemców zredukował do pokarmu dla robaków.

W numerze 9, który ukazał się z datą 2 sierpnia, pokazano rozmowy prowadzone między Niemcami. Pierwszy rysunek przedstawia dwóch ofermowatych żołnierzy - Fryca i Hansa, którzy zapoznali się z obwieszczeniem informującym, że za zabicie partyzanta Daniły zabójca otrzyma nagrodę w wysokości $300 \mathrm{rubli}^{43}$. „Bardzo tanio wycenili nasze głowy" - skomentował Fryc. „Jak to" - pyta zdziwiony Hans. "A tak! Partyzant Daniła zabił 300 żołnierzy niemieckich" 44 - odpowiedział Fryc.

Drugi rysunek przedstawia dialog dowódcy żandarmów z podwładnym, który wraz z dwoma innymi żołnierzami miał powiesić partyzanta Mikitę. „Co to jest, dwóch zabitych Niemców? A gdzie partyzant Mikita?” - pytał hitlerowiec podwładnego żandarma. „Partyzant Mikita, jak należało się spodziewać, okazał się wielkim tchórzem. Nie chciał wleźć pod szubienicę. Przypadkiem zabijając dwóch naszych wartowników, uciekł ze strachu" - odpowiedział żandarm.

Całość numeru ze świętą dla bolszewików datą 7 listopada wypełnia rysunek przedstawiający partyzanta miotającego granaty. Niemcy z pourywanymi od wybuchów głowami i kończynami fruwają w powietrzu.

42 „Партызанская дубінка” (22 III 1942), № 1.

43 Ruble sowieckie do końca 1942 r. były środkiem płatniczym w okupowanej Białorusi.

44 „Партызанская дубінка” (2 VIII 1942), № 9. 


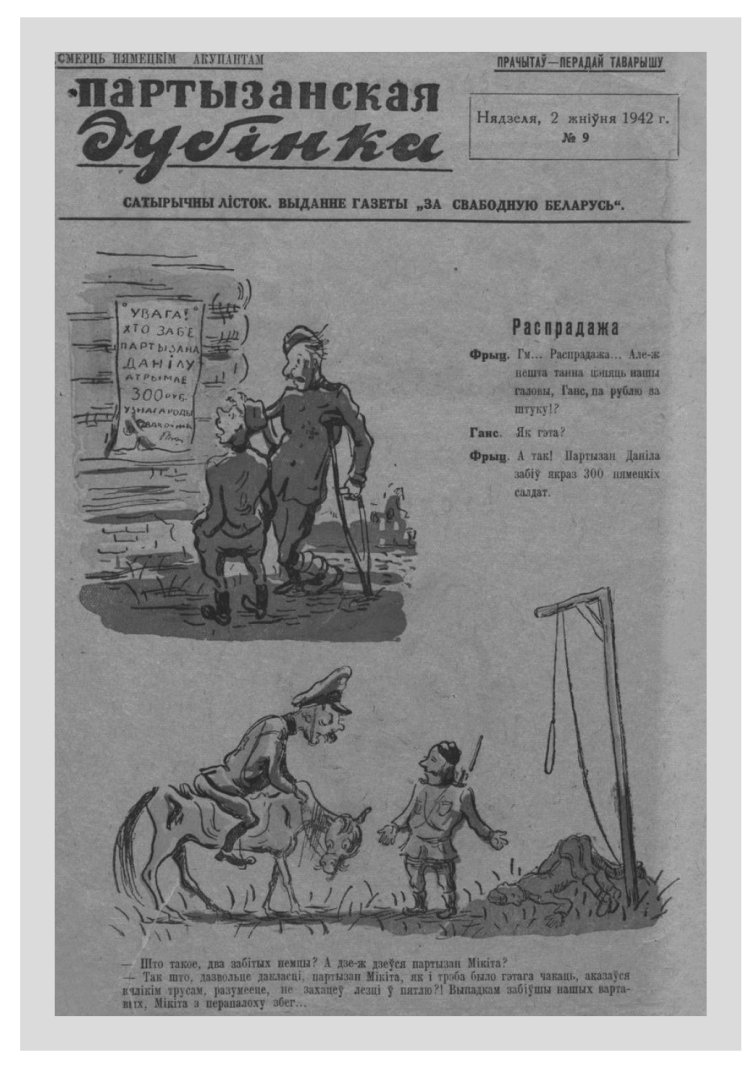

6. „Partyzancki Kij” (2 VIII 1942), nr 9.

Po przełomie stalingradzkim na początku 1943 r., podobnie jak w innych pismach wydawanych pod kuratelą KC $\mathrm{KP}(\mathrm{b}) \mathrm{B}$, gloryfikacja czynu partyzanckiego schodziła na drugi plan. Na polu zasług militarnych eksponować zaczęto przede wszystkim rolę Armii Czerwonej. W przedostatnim wydanym numerze „Partyzanskiej dubinki” na pierwszym planie jest już czerwonoarmista, a napis głosi: „Sława Armii Czerwonej! Sława sowieckim partyzantom!”45.

Ostatni marcowy numer (1943, nr 19) już nic nie wspominał o partyzantach. $\mathrm{Na}$ stronie tytułowej satyryczny obraz ostatniej defilady armii niemieckiej na tle ruin Berlina. Na pierwszym planie żołnierz kaleka. Sugerowano, że tylko w takim stanie żywi Niemcy będą mogli powrócić z wojny na Wschodzie.

$\mathrm{Na}$ odwrotnej stronie okaleczony i beznogi Hitler na kulach, a na bandażach, którymi był owinięty, miejsca, gdzie armia niemiecka poniosła klęski - Moskwa, Stalingrad, Kaukaz, Don. Na początku 1943 r. zapowiadano: „tak będzie wyglądała ostatnia parada Hitlera"46. Przekaz ten adresowano także do kilkudziesięciu

45 „Партызанская дубінка” (II 1943), № 18.

46 „Партызанская дубінка” (III 1943), № 19. 


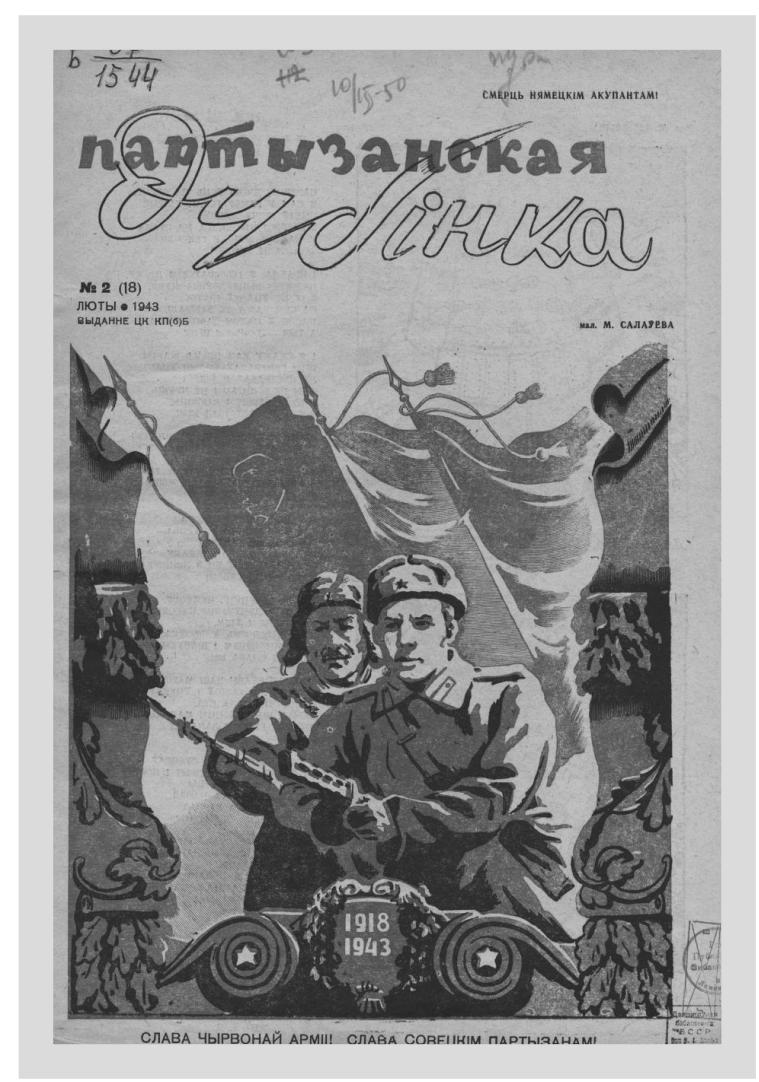

7. „Partyzancki Kij” (II 1943), nr 2 (18).

tysięcy Białorusinów, którzy znaleźli się w strukturach niemieckiej władzy okupacyjnej jako urzędnicy, nauczyciele, policjanci, dziennikarze, pracownicy kultury. Na przekór niemieckiej propagandzie przekonywano, że klęska III Rzeszy jest nieuchronna i wkrótce nadejdzie czas rozliczeń z wykonania obowiązków wobec sowieckiej ojczyzny.

W propagandzie sowieckiej najczęściej eksponowano karykaturę Adolfa Hitlera. Był on symbolem III Rzeszy i wszystkich zbrodni popełnianych przez Niemców na okupowanych terytoriach. W niemieckiej propagandzie takie samo miejsce zajmował Józef Stalin.

Po zatrzymaniu ofensywy niemieckiej pod Moskwą w grudniu $1941 \mathrm{r}$. i w wyniku kontrofensywy Armii Czerwonej, na styku grup armii niemieckich „Północ” i „Centrum”, między miastami Wieliż i Uświaty, powstał 40-kilometrowy wyłom zwany „Bramą Witebską”. „Brama” ta przetrwała od lutego do września 1942 r. W tym czasie zza linii frontu na teren okupowanej Białorusi wysłano kilkadziesiąt grup dywersyjnych, broń, medykamenty, mundury dla partyzantów, miliony egzemplarzy gotowej literatury oraz sprzęt do poligrafii w polowych 


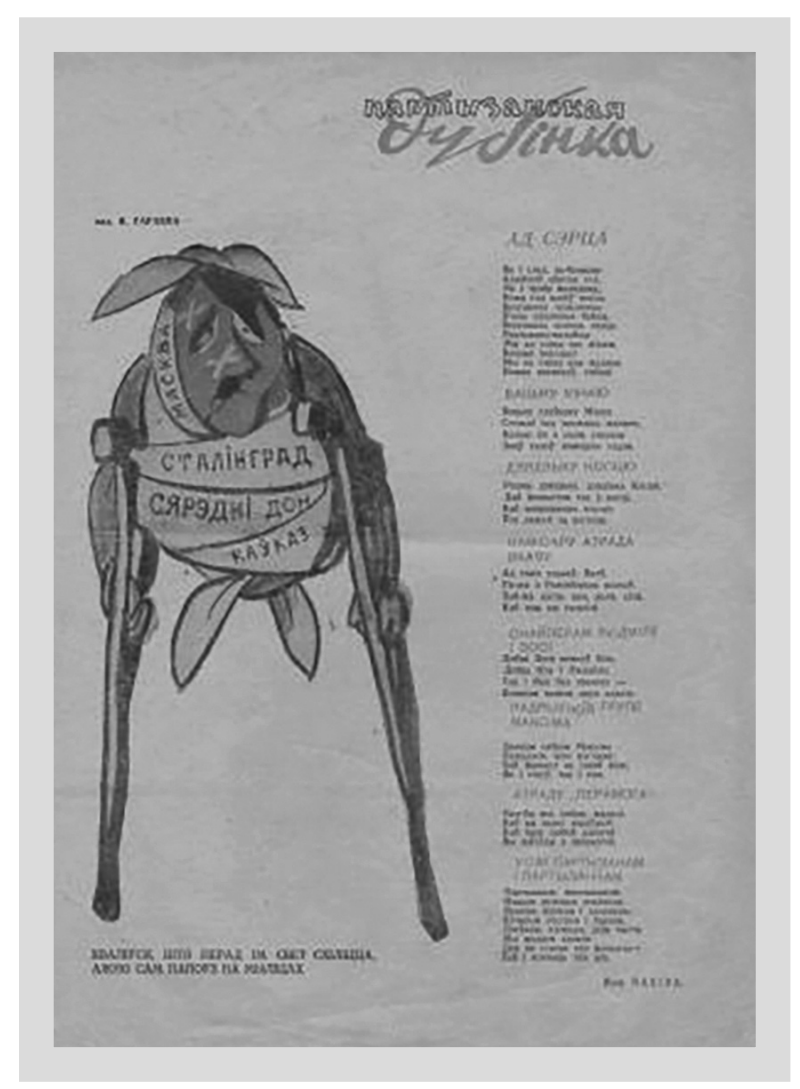

8. „Partyzancki Kij” (III 1943), nr 19.

warunkach wraz drukarzami i specjalistami od propagandy ${ }^{47}$. Dzięki temu możliwe było uruchomienie podziemnych wydawnictw nie tylko szczebla obwodowego, lecz także rejonowego.

Masowy napływ rekrutów do oddziałów partyzanckich w 1943 r. nasuwał także w kierownictwie radzieckim pytanie o bierność tych obywateli, a zwłaszcza komunistów w czasie, gdy ważyły się losy państwa ${ }^{48}$. Brak zaufania do nowych żołnierzy podziemia rodził potrzebę kontroli politycznej i wzmożonej wśród nich pracy ideologicznej.

W 1943 r. perspektywa wygrania wojny przez ZSRR stawała się coraz bardziej realna. Działalność propagandową wśród społeczeństwa na okupowanych obszarach traktowano jako przygotowanie do powrotu władzy radzieckiej. Racjonalnie bowiem oceniano, że dwuletni okres indoktrynacji niemieckiej mógł naruszyć fundamenty ideologii bolszewickiej. Propagandzie na rzecz przywracania zaufania

\footnotetext{
${ }^{47}$ J. Turonek, Białoruś pod okupacja niemiecka, Warszawa 1993, s. 110-111.

${ }^{48}$ K. Slepyan, op. cit., s. 245-246.
} 


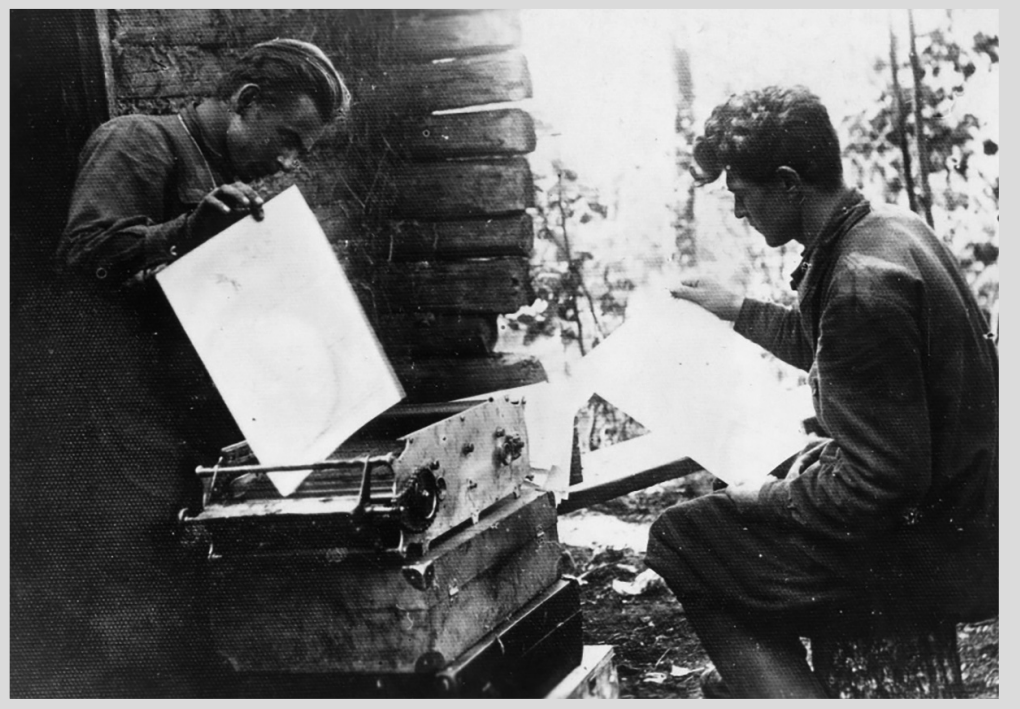

9. Poligrafia Czerwieńskiego Komitetu Rejonowego KP(b)B, maj 1943 r., NARB, f. 1487 , op. 1, sp. 165 , k. 2.

do państwa radzieckiego na okupowanych obszarach nadano taką samą rangę, jak działalności dywersyjnej.

Gazety wydawane przez rejonowe komitety $\mathrm{KP}(\mathrm{b}) \mathrm{B}$ niewiele różniły się od gazet będących organami prasowymi KC. Jednokartkowe pisma, które zaczęły się ukazywać w 1943 r., informowały głównie o sukcesach Armii Czerwonej i niebudzących najmniejszej wątpliwości decyzjach Stalina. Przykład może stanowić organ Pleszczannickiego Komitetu Rejonowego KP(b)B „Leninowiec” („Ленинец”). Gazeta była wydawana w języku rosyjskim i zupełnie pozbawiona treści odnoszących się do sytuacji w rejonie.

Pierwszy numer „Leninowca” wyszedł z datą 8 marca 1943 r., jako gazeta codzienna sowieckiego podziemia $w$ rejonie. Ponad $2 / 3$ materiału stanowi wykaz zwycięstw i wyzwolonych miast przez Armię Czerwoną.

Wydarzeniem, o którym wydawcy chcieli poinformować mieszkańców okupowanej białoruskiej prowincji, było nadanie Stalinowi przez Radę Najwyższą tytułu Marszałka Związku Radzieckiego. Pod portretem wodza informacja o spontanicznych mityngach $z$ tej okazji, organizowanych przez załogi pracownicze, gratulacjach i pozdrowieniach wysyłanych przez radujących się robotników. Obywatelom sowieckim rejonu pleszczannickiego nieustannie przypominano, że po drugiej stronie frontu jest genialny wódz i jego władza, która niebawem powróci na Białoruś.

Trzeci numer ukazał się z datą 5 kwietnia 1943 r. Pierwsza strona niewiele różniła się od gazet republikańskich lub centralnych. Najważniejsza informacja dotyczyła ustanowienia przez Prezydium Rady Najwyższej ZSRR medalu „Partyzant 
Wojny Ojczyźnianej” oraz opisu warunków do spełnienia, by otrzymać to odznaczenie. Krótki wiersz w języku białoruskim streszczał te warunki:

Хто фашыстаў з тылу косіць, Цвёрды хто ў баях, як сталь, На грудзях своіх той носіць, Пратызанскую медаль ${ }^{49}$.

Można przypuszczać, że dla zwykłego Białorusina, pragnącego przetrwać koszmar okupacji, informacje o medalach dla partyzantów nie miały wielkiego znaczenia. Partyzanci w okolicy to pretekst dla Niemców do pacyfikacji. Ponadto wojsko to pozbawiało mieszkańców deficytowej żywności i wszelkich dóbr, podobnie jak Niemcy. Rzeczywistość mocno różniła się od partyzanckiego mitu.

Na odwrotnej stronie został umieszczony artykuł pt. Zapamiętamy i pomścimy - o pacyfikacji wioski Chatyń, gdzie ukraińscy policjanci pod dowództwem niemieckich oficerów zamordowali 149 mieszkańców, w tym 75 dzieci. Pretekstem do pacyfikacji Chatynia było zastrzelenie przez partyzantów w pobliżu wsi niemieckiego oficera.

Ważne zadanie zlecone partyzantom latem 1942 r. przez Centralny Sztab Ruchu Partyzanckiego, kierowany przez I sekretarza KC KP(b)B Ponomarienkę, stanowiła likwidacja urzędów administracji gminnej i zatrudnionych tam pracowników wraz $\mathrm{z}$ rodzinami ${ }^{50}$. Śmiercią karano także nauczycieli uczących w szkołach białoruskich, sołtysów, a w niektórych wypadkach także chłopów, którzy przyjęli ziemię w wyniku parcelacji kołchozów. Ludzie ci byli zabijani jako zdrajcy radzieckiej ojczyzny. Palono wsie, których mieszkańców uznano za skłonnych do współpracy z Niemcami ${ }^{51}$. Wśród zabitych przez radzieckie podziemie ponad $75 \%$ stanowili sołtysi, urzędnicy gminni, nauczyciele, inicjatorzy życia narodowego oraz członkowie ich rodzin ${ }^{52}$. Propaganda w żaden sposób nie odzwierciedlała istniejących podziałów i konfliktów. Pokazywała świat czarno-biały, z jednej strony Niemców - „potworów i faszystów”, z drugiej, zjednoczony pod przewodnictwem Stalina, dzielny naród radziecki.

O partyzantach, których obecnością w okolicy Niemcy usprawiedliwiali pacyfikacje, rabunek mienia i mord ludności cywilnej, gazety sowieckiego podziemia informowały wyłącznie jako o bohaterach. Nie wspominano, że ich obecność $\mathrm{w}$ jakiejś okolicy prowokuje niemieckie represje. Nigdy także nie pojawiały się

\footnotetext{
49 W dosłownym tłumaczeniu:

„Kto faszystów z tyłu kosi,

W boju twardy jest, jak stal,

Ten na piersiach swoich nosi

Partyzancki medal”. „Ленинец” (5 IV 1943), № 3.

50 Всенардное партизанское движение в Белоруссии в годы Великой Отечественной войны (июнь 1941 - июль 1944) Документы и матерялы, т. 1, Минск 1967, с. 477-478.

51 Z. Szybieka, Historia Białorusi 1975-2000, Lublin 2002, s. 349.

52 J. Turonek, op. cit., s. 116-117.
} 
w partyjnej prasie, chociażby w formie refleksji, próby odpowiedzi na pytanie: dlaczego partyzanci nie uchronili mieszkańców jakiejkolwiek wsi przed pacyfikacją?

Część tytułów jednokartkowych pism komitetów rejonowych partii stanowiła kontynuację gazet ukazujących się przed wybuchem wojny. To m.in.: „Awangarda” („Авангард”), „Bolszewik Polesia” („Бальшавік Палесся”), „Bolszewicki Sztandar” („Бальшавіцкі сцяг”), „Bolszewicka Trybuna” („Бальшавіцкая трыбуна”), „Grodzieńska Prawda” („Гродненская правда”), „Homelska Prawda” („Гомельская праўда”), „Za bolszewickie kołchozy” („За балшавціцкія калгасы”). Wznowiono ich wydawanie w 1943 r., a niektórych na początku 1944 r. Część tytułów miała jedynie kilka numerów. Treść wszystkich była podobna. Artykuły opowiadały o sytuacji na froncie, prezentując kolejne zwycięstwa Armii Czerwonej. Publikowano te same decyzje i rozkazy Stalina, które ukazywały się w gazetach centralnych i republikańskich. Sporadyczne były wzmianki o tym, co działo się $\mathrm{w}$ rejonie, który reprezentował dany komitet $\mathrm{KP}(\mathrm{b}) \mathrm{B}^{53}$.

W 1943 r. tworzono także nowe pisma komitetów rejonowych, jak np. „Bobrujski Partyzant” („Бобруйский партызан”), „Do boju za Ojczyznę” („В бой за Родину”), „Śmierć okupantom” („Смерть окупантом”), „Czerwony Partyzant” („Чырвоны партызан”). Wszystkie prezentowały podobne treści, jak te, które stanowiły kontynuację przedwojennych tytułów. Zapewne komunikaty do druku przesyłano z tego samego źródła.

W sytuacji oczekiwanych powojennych rozliczeń pozostawieni w konspiracji działacze partii chcieli wykazać się własnym wkładem w walkę z okupantem i oddaniem przywódcy państwa sowieckiego. Stąd hołdowniczy wobec Stalina ton większości publikacji.

W pismach wydawanych w ostatnich miesiącach wojny przywracano zasady publikacji materiałów prasowych, obowiązujące przed 22 czerwca $1941 \mathrm{r}$. Dotyczyło to także sposobu rozmieszczenia fotografii. Podobnie jak w ikonografii religijnej eksponowana była najważniejsza figura z panteonu sowieckich dostojników. Stalin zawsze znajdował się w centrum. Jego portret był większych rozmiarów lub umieszczany wyżej od innych funkcjonariuszy, którzy dostąpili zaszczytu bycia w otoczeniu wodza.

\section{The Soviet Press Propaganda in German-Occupied Belorussia 1941-44}

\section{Abstract}

The Soviet propaganda in Belorussia was totally subordinated to the Central Committee of the Communist Party (Bolsheviks) of Belorussia. In the first stage of the war, it was to offer a clear answer to the questions: Who the Germans were? What was the actual combat for the inhabitants of the USSR? And what should be the attitude of the Soviet citizen? Propaganda, defining the occupiers as 'murderers', 'bloodthirsty beasts', and 'monsters' programmed to kill,

53 Памяць палаючых гадоў. 70-годдзю Вялікай Перамогі прысвячаециза алічбаваныя калекиыі 3 фондаў Нацыянальнай бібліятэкі Беларусі, http://old.nlb.by/vov70/index.php?path=/catalogue/view-400\&menu_id=228 (dostęp: 7.02.2019). 
violate, and rob Soviet people, was to convince that a biological war for the survival of the Belarussian nation was being waged. The only chance to win was to exterminate the 'monsters'. The simplest way to fulfil one's duty towards the nation and the country was a military struggle in guerrilla formations or support for those who conducted such struggle.

A vast majority of newspapers and all propaganda materials were published in Belarusian. There were 165 titles of Russian papers distributed throughout the occupied Belarusian territories, including 3 central ones, 3 republican, 14 district, and 145 regional. The greater part was a single-leaf papers. The most popular and influential was the Soviet Belarus, the organ of the Central Committee of the $\mathrm{CP}(\mathrm{B})$. The most appealing to the imagination were satirical papers, with a special place among them occupied by the Let's Crush the Nazi Reptile.

In 1943, editorial boards were ordered to publish such materials as to reconstruct the trust in the Soviet state among the people under the German occupation. These activities were given the same importance as the motivation to the struggle against the occupiers before.

\section{Советская газетная пропаганда на оккупированной Германией Белоруссии 1941-1944}

\section{Аннотация}

Советская пропаганда на Белоруссии полностью координировавшаяся Центральным комитетом Коммунистической партии (большевиков) Белоруссии. В первый период войны она получила задачу однозначно ответить на вопрос, кто такие немцы, чем для жителей СССР является идущая война, а также какое отношение должен проявить советский гражданин. Пропаганда, определяющая оккупантов как «убийц», «кровожадные бестии» и «монстров», которых целью было убить, взять в плен и грабить советские народы, убеждала, что идет война за биологическое выживание белорусской нации. Единственным шансом выжить - было уничтожение «монстров». Простейшим способом исполнить долг перед нацией и отечеством была вооруженная борьба в партизанских отрядах или оказание помощи тем, кто вел такую войну.

Преобладающее большинство газет и всякого рода агитационно-пропагандистских материалов печаталось на белорусском языке. На оккупированной территории Белоруссии распространялись 165 названий советских газет, включая 3 центральные, 3 республиканские, 14 областных и 145 районных. Большинство из них - это однолистные издания. Самой влиятельной была газета «Советская Белоруссия» являвшаяся органом ЦК КП(б)Б. Пропагандистскими материалами, которые сильнее всех будоражили воображение, были сатирические издания. Исключительное место среди них было отведено периодическому изданию «Раздавим фашистскую гадину».

В 1943 г. редакционным коллективам газет было приказано печатать материалы с содержанием, которое должно было вернуть доверие к советскому государству у населения, остававшегося под немецкой оккупацией. Этим действиям была присвоена такая же значимость, как раньше та, которую получила мобилизация для борьбы с оккупантом.

\section{Bibliografia}

\section{Źródła}

Narodowe Archiwum Republiki Białoruś

Всенардное партизанское движение в Белоруссии в годы Великой Отечественной войнь (июнь 1941 - июль 1944) Документы и матеряль, т. 1, Минск 1967. 
Памяць палаючых гадоў. 70-годдзю Вялікай Перамогі прысвячаециза алічбаваныя калекиьі 3 фондаў Нацьянальнай бібліятэкі Беларусі, http://old.nlb.by/vov70/index.php?path=/ catalogue/view-400\&menu_id=228 (dostęp: 7.02.2019).

Преступления немецко-фашистских окупантов в Белоруссии, ред. П.П. Липпило, В.Ф. Романовский, Минск 1965.

\section{Gazety}

„За Савецкую Беларусь”

„Звязда”

„Ленинец"

„Партызанская дубінка”

„Раздавім фашысцкую гадзіну”

„Советская Бедоруссия”

\section{Opracowania}

Slepyan K., Partyzanci Stalina. Radziecki ruch oporu w czasie II wojny światowej, Poznań 2008. Szybieka Z., Historia Białorusi 1975-2000, Lublin 2002.

Turonek J., Białoruś pod okupacja niemiecka, Warszawa 1993.

Болсун Г., Паротивостояние немеикой и советской пропаганды на окупированой теритрии Беларуси (1941-1944), mps pracy doktorskiej, Минск 1999.

Болсун Г., Паротивостояние немеикой и советской пропаганды на окупированой теритрии Беларуси (1941-1944), в: Беларусь 1941-1945. Подвиг. Трагедия. Память, кн. 1, Минск 2010, с. 432-452.

Лысова Т., Как советская пропаганда подавляла нцыскую, „Рэспубліка”, http://bsj. by/2013/07/smi-i-vojna-kak-sovetskaya-propaganda-podavlyala-nacistskuyu (dostęp: 12.05.2018).

Стыкалин С., Советская сатирическая печать 1917-1963. Партызанская дубінка, https:// info.wikireading.ru/249308 (dostęp: 12.03.2019).

Факторович А., Крах аграрной политики немецик-фашистских окупантов в Белоруссии, Минск 1979.

Eugeniusz Mironowicz, prof. dr hab., kierownik Katedry Stosunków Międzynarodowych i Historii Współczesnej na Wydziale Historii i Stosunków Międzynarodowych Uniwersytetu w Białymstoku. Zainteresowania badawcze: polityka zagraniczna krajów postradzieckich, najnowsza historia Białorusi, problemy etniczne w krajach Europy Wschodniej (ebma@interia.pl).

Eugeniusz Mironowicz, prof. dr. hab., head of the Department of International Politics at the Institute of History and Political Science, University of Bialystok. His research interests include: foreign policy of post-Soviet countries, recent history of Belarus, ethnic problems in Eastern European countries (ebma@interia.pl). 